\title{
Investigating OCB's Mediating Effect of School Organizational Justice on Teachers' Performance: Evidence from Indonesia
}

\author{
C. Chandrawaty ${ }^{1}, \mathrm{~W}$. Widodo $^{2 *}$
}

${ }^{1}$ Faculty of Teacher Training and Education, Universitas Muhammadiyah Prof. Dr. HAMKA, Jakarta, Indonesia ${ }^{2}$ Universitas Indraprasta PGRI, Jakarta, Indonesia

Article History

Received: 08.02.2021

Accepted: 04.04.2021

Published: 09.04.202

Journal homepage: https://www.easpublisher.com

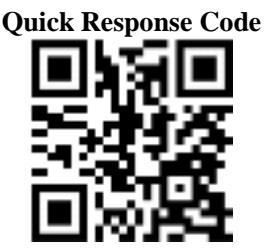

Abstract: This study investigates the empirical effect of school organizational justice (SOJ) and organizational citizenship behavior (OCB) on teachers' performance and proves the theoretical model regarding OCB as a mediator between SOJ and teachers' performance. A questionnaire collected research data. The questionnaire for all research variables is reliable with an alpha coefficient $>$.7. The research participant is 455 teachers of the public elementary schools in Indonesia select by accidental sampling. Data analysis uses path analysis supported by descriptive statistics and correlational matrics. The research result reveals that SOJ and OCB significantly affect teachers' performance. SOJ is also significantly influenced teachers' performance. Besides, OCB was significantly indirectly mediating the effect of SOJ on teachers' performance. The empirical model of SOJ on performance mediating by OCB was confirmed. This model can discuss among researchers and educational practitioners to build models of performance that can adapt as new approaches or strategies to enhancing teachers' performance. Therefore, the research suggested that the teachers' performance can improve through SOJ and OCB.

Keywords: School Organizational Justice, OCB, Performance, Teacher, Indonesia.

Copyright (C) 2021 The Author(s): This is an open-access article distributed under the terms of the Creative Commons Attribution 4.0 International License (CC BY-NC 4.0) which permits unrestricted use, distribution, and reproduction in any medium for non-commercial use provided the original author and source are credited.

\section{INTRODUCTION}

Performance, including teachers' performnace in school organizational contexts, is consistently a critical issue in several decades recently because its existence is related to individual performance, which strongly determines the organizations' life, both profit and non-profit organizations. Individual performance is proven to increase organizational effectiveness [1] and organizational performance [2]. For Aguinis [3], performance is about behavior or what employees do. The performance also refers to a set of employee workrelated behaviors designed to accomplish organizational goals [4] and the value of the set of employee behavior that contributes, either positively or negatively, to organizational goal accomplishment [5]. Hence, performance can view from a perspective on contextual performance, which includes those behaviors that contribute to the organizations' effectiveness by providing a suitable environment in which task performance can occur, such as persisting with enthusiasm and exerting extra effort as necessary to complete one's task activities successfully; volunteering to carry out task activities that are not formally part of the job; helping and cooperating with others; following organizational rules and procedures; and endorsing, supporting, and defending organizational objectives [3].
This also applies to teachers in the school organizations' context in Indonesia. In this context, teacher performance is related to a set of employee workrelated behaviors designed and contributes to accomplishing school goals through persisting with enthusiasm and exerting extra effort as necessary to complete one's task activities successfully; volunteering to carry out task activities that are not formally part of the job; helping and cooperating with others; following school organizational rules and procedures; and endorsing, supporting, and defending school organizational objectives. Thus, as happens in other organizations, teacher performance can also influence and determine school organizational effectiveness and performance. Therefore, teacher performance is essential to research, especially from the perspective of SOJ and OCB.

\section{LITERATURE REVIEW AND HYPOTHESIS DEVELOPMENT SOJ and Teachers' Performance}

Every employee, including teachers as schools' members and employees, wants to be needed fairly in their work. Such justice is commonly referred to as organizational justice. According to Muchinsky [6], 
organizational justice is the fair treatment of a person in the organization. For Ivancevich, Konopaske, \& Matteson [4], organizational justice is related to the extent to which individuals feel treated fairly in the workplace. Organizational justice is also how fairly employees feel that the company treated them [7]. Moreover, organizational justice refers to a persons' perception of fairness within the organization, which includes perceptions of how decisions are made in relation to the distribution of results and perceptions of fairness for the outcomes themselves [8, 9]. Aamodt [10] states that organizational justice has three dimensions, which are distributive, procedural, and interactional justice. Distributive justice is related to the perceived fairness of the actual decision made in an organization. Procedural justice is referred to the perceived fairness of the method used to arrive at a decision. Meanwhile, interactional justice related to the perceived fairness of the interpersonal treatment received. Organizational justice can also occur in school organizations. In this perspective, school organizational justice (SOC) can be interpreted as teachers' perception or feel treated fairly in the workplace and school organization reflected in distributive, procedural, and interactional justice. If in good condition, these dimensions can stimulate increasing teachers' performance manifested in persisting with enthusiasm and exerting extra effort as necessary to complete one's task activities successfully; volunteering to carry out task activities that are not formally part of the job; helping and cooperating with others; following organizational rules and procedures; and endorsing, supporting, and defending organizational objectives [3]. The scholars also claimed that organizational justice affects teachers' performance [11-15]. Based on the argues and studies above, the first hypothesis in this study is:

\section{$\mathbf{H}_{1}$ : SOJ had a direct effect on teachers' performance.}

\section{$O C B$ and Teachers' Performance}

$\mathrm{OCB}$, in several decades, is an essential factor for the organization, including school organizations. Several studies indicated that OCB affects productivity [16] and organizational performance [17]. The scholars state that OCB related to employee behavior that is beyond the call of duty, exceeds formal job duties, such as cooperation and helpfulness to others that support the organizations' social and psychological context, but is often necessary for organizational survival [18, 19]. OCB is also referring to the set of behaviors that sustain or enhance the organizations' cooperative system but are not systematically or generally recorded in the organizations' formal system or tied in any consistent way to specific rewards [20]. OCB is also included such behaviors as taking on additional assignments, voluntary assisting other people at work, keeping up with the developments in one's field or profession, following company rules even when no one is looking, promoting and protecting the organization, and keeping a positive attitude and tolerating inconveniences at work [7]. OCB consists of five indicators, which are altruism, conscientiousness, sportsmanship, courtesy, and civic virtue [21]. These indicators, if at a high level, can be someone who enhances their performance. The researchers' investigation [22-25] shows that OCB influences performance. Based on argues and studies above, the second hypothesis in this study is:

$\mathbf{H}_{2}$ : OCB had a direct effect on teachers' performance.

\section{SOJ and OCB}

SOJ is also affecting OCB besides performance. The school with distributive, procedural, and interactional justice [10] stimulates enhancing teachers' OCB, such as altruism, conscientiousness, sportsmanship, courtesy, and civic virtue [21]. For example, Schools that treat teachers fairly will inspire and encourage awareness and helpful behavior among teachers. The research carried out by researchers [2631] also indicate that organizational justice related to OCB. Based on argues and studies above, the third hypothesis in this study is:

$\mathbf{H}_{3}$ : SOJ had a direct effect on OCB.

SOJ and Teachers' Performance Mediating by $O C B$

From the various results of the research above, OCB mediates SOJs' effect on teachers' performance. The school that has distributive, procedural, and interactional justice [10] can stimulate enhancing teachers' OCB, such as altruism, conscientiousness, sportsmanship, courtesy, and civic virtue [21] and then implicate to teachers' performance manifested in persisting with enthusiasm and exerting extra effort as necessary to complete one's task activities successfully; volunteering to carry out task activities that are not formally part of the job; helping and cooperating with others; following organizational rules and procedures; and endorsing, supporting, and defending organizational objectives [3]. The studies carried out by scholars [28-31] proved that SOJ has a significant correlation with OCB, while the studies conducted by scholars [32, 33, 17, 34] claimed that OCB affects performance. Based on argues and studies above, the fourth hypothesis in this study is:

$\mathbf{H}_{4}$ : SOJ had an indirect effect on teachers' performance mediating by $O C B$.

\section{RESEARCH METHODS}

This research uses a quantitative approach to the survey method through a Likert scale model questionnaire with five option answers: strongly disagree, disagree, neutral, agree, and strongly agree to verify the hypotheses [35]. The questionnaire makes researchers themselves based on the theoretical dimensions or indicators from the experts. SOJ 
indicators are distributive, procedural, and interactional justice [10]. OCB consists of five indicators: altruism, conscientiousness, sportsmanship, courtesy, and civic virtue [21]. The performance consists of five indicators: persisting with enthusiasm and exerting extra effort as necessary to complete one's task activities successfully; volunteering to carry out task activities that are not formally part of the job; helping and cooperating with others; following organizational rules and procedures; and endorsing, supporting, and defending organizational objectives [3]. SOJ consists of 6 items with an alpha coefficient $=.874, \mathrm{OCB}$ consists of 10 items with an alpha coefficient $=.874$, and performance consists of 10 items with alpha coefficients $=.796$. All variables have an alpha coefficient $>.7$, so it is reliable as a research instrument $[36,35]$.

The research participant is 455 teachers of the public elementary school in Indonesia spread across seven provinces (Jakarta, Banten, West Java, Central Java, Riau Island, NTT, and East Kalimantan) determined by accidental sampling based on participant willingness to fill in the questionnaire at the time the research was conducted [37].

Table-1: Profile of the Research Participant

\begin{tabular}{|c|c|c|}
\hline Profile & Amount & Percentage \\
\hline \multicolumn{3}{|l|}{ Gender } \\
\hline 1. Male & 89 & 19.56 \\
\hline 2. Female & 366 & 80.44 \\
\hline \multicolumn{3}{|l|}{ Age } \\
\hline 1. $\leq 25$ Year & 19 & 4.18 \\
\hline 2. $26-35$ Year & 122 & 26.81 \\
\hline 3. $36-45$ Year & 154 & 33.85 \\
\hline 4. $46-55$ Year & 101 & 22.20 \\
\hline 5. $\geq 56$ Year & 59 & 12.97 \\
\hline \multicolumn{3}{|l|}{ Education } \\
\hline 1. Diploma (D3) & 37 & 8.13 \\
\hline 2. Bachelor (S1) & 407 & 89.45 \\
\hline 3. Postgraduate (S2) & 11 & 2.42 \\
\hline 4. Doctoral (S3) & 0 & 0 \\
\hline \multicolumn{3}{|l|}{ Status } \\
\hline 1. Married & 421 & 92.53 \\
\hline 2. Unmarried & 34 & 7.47 \\
\hline \multicolumn{3}{|l|}{ Length of Teaching } \\
\hline 1. $\leq 5$ Year & 79 & 17.36 \\
\hline 2. $6-10$ Year & 49 & 10.77 \\
\hline 3. $11-15$ Year & 161 & 35.38 \\
\hline 4. $\geq 16$ Year & 166 & 36.48 \\
\hline
\end{tabular}

As present in Table-1, the majority of gender is female $(80.44 \%)$, ages 36 - 45 years $(33.85 \%)$, bachelor education $(89.45 \%)$, marital status $(92.53 \%)$, and length of teaching $\geq 16$ years $(36.48 \%)$. Data analysis by path analysis and to test the significance of the path coefficient uses a t-test supported by correlational and descriptive statistics. Descriptive analyzes were performed by SPSS version 22, while the path analysis by LISREL 8.80 .

\section{RESUlT AND DiscuSSION}

The descriptive statistical analysis result for the three research variables are present as follows in Table2. The mean values of the three variables from the lowest to the highest in succession are SOJ (24.77), teachers' performance (40.52), and OCB (41.54). The correlation analysis results in all variables have significant relationships with the other variables at level $\mathrm{p}<.01$. This condition indicates that all the variables have a mutual relationship with each other. The correlation coefficient from the lowest to the highest in succession are SOJ and performance (.420), SOJ and OCB (.432), and OCB and performance (.749).

Table-2: Descriptive Statistics and Correlation Matrix

\begin{tabular}{|l|r|l|l|l|l|}
\hline Variables & Mean & Std. Deviation & $\mathbf{1}$ & $\mathbf{2}$ & $\mathbf{3}$ \\
\hline 1. SOJ & 24.77 & 4.052 & 1.00 & & \\
\hline 2. OCB & 41.54 & 4.750 & $.432 * *$ & 1.00 & \\
\hline 3. Teachers' Performance & 40.52 & 5.025 & $.420 * *$ & $.749 * *$ & 1.00 \\
\hline \multicolumn{7}{|c|}{$* * .01$} \\
\hline
\end{tabular}


The results of hypothesis testing with path analysis of the effects of SOJ on teahers' performance mediating by OCB are summarized in Table 3 and visualized in Figure 1 and 2. All of the hypotheses were supported ( $\mathrm{t}$ value $>\mathrm{t}$ table at $\alpha=.01$ ). Therefore the result of this study revealed that SOJ had a significant direct effect on teachers' performance, OCB had a significant direct effect on teachers' performance, SOJ had a significant direct effect on OCB, and SOJ had a significant indirect effect on teachers' performance mediating by OCB. The direct effect of SOJ on OCB (.43) was greater than that of teachers' performance (.12). The indirect effect of SOJ on teachers 'performance through OCB (.30) was also greater than the direct effect of SOJ on teachers' performance (.12). This shows that the existence of OCB as a mediating variable is vital for teachers' performance.

Table-3: Summary of Path Coefficients and T Values

\begin{tabular}{|l|l|l|l|}
\hline Hypothesis & Path Coefficients & T Value & Hypothesis Testing \\
\hline $\mathrm{H}_{1}:$ SOJ $(\mathrm{X})$ on teachers' performance $\left(\mathrm{Y}_{2}\right)$ & $.12^{* *}$ & 3.53 & Supported \\
\hline $\mathrm{H}_{2}:$ OCB $\left(\mathrm{Y}_{1}\right)$ on teachers' performance $\left(\mathrm{Y}_{2}\right)$ & $.70^{* *}$ & 20.40 & Supported \\
\hline $\mathrm{H}_{3}:$ SOJ $(\mathrm{X})$ on OCB $\left(\mathrm{Y}_{1}\right)$ & $.43^{* *}$ & 10.19 & Supported \\
\hline $\begin{array}{l}\mathrm{H}_{4}: \text { SOJ }(\mathrm{X}) \text { on teachers' performance }\left(\mathrm{Y}_{2}\right) \\
\text { mediating by OCB }\left(\mathrm{Y}_{1}\right)\end{array}$ & $.30^{* *}$ & 9.12 & Supported \\
\hline \multicolumn{2}{|l}{$\mathrm{p}<.01$} & & \\
\hline
\end{tabular}

In Figure 1 and 2, the test results of the model with the goodness of fit statistics show the significant with Chi-Square $=0.000, \mathrm{df}=0, \mathrm{p}$-value $=1.00000\rangle$ .05 and RMSEA $=.000<.08$. That means the model tested is fit. This result indicates that the theoretical

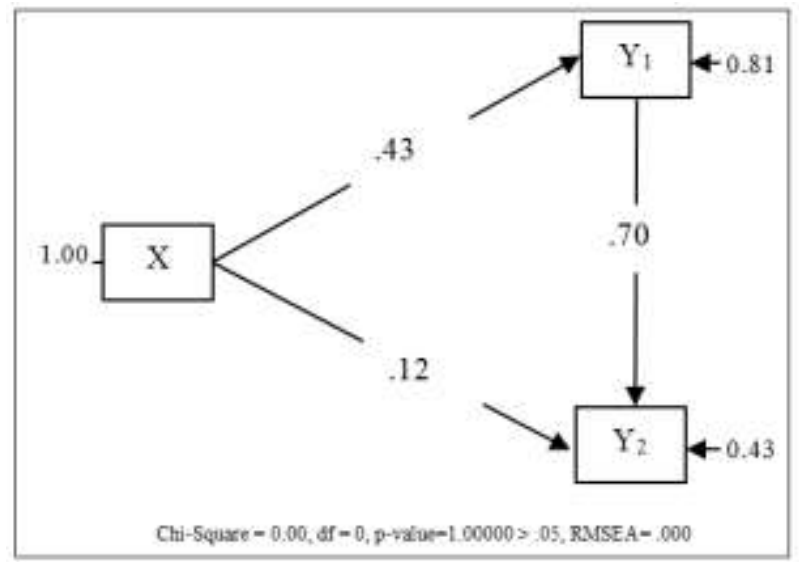

Fig-1: Path Coefficients

This research proved that SOJ significantly affected teachers' performance, directly or indirectly mediating by OCB. The indirect effect of SOJ on teachers' performance through OCB greater than the direct effect of SOJ on teachers' performance. This shows that the existence of $\mathrm{OCB}$ as a mediating variable is vital for teachers' performance. This evidence addreses that OCB plays a significant role as a mediator of the effect of SOJ on teachers' performance. This research also indicates the vitality of SOJ and OCB for teachers' performance. That means the existence of SOJ and OCB are important determinants for enhancing teachers' performance. This is similar and consistent with studies conducted by researchers that performance influenced by SOJ [29-31], and OCB [22-25]. model being test is supported by empirical data from teachers of the public elementary schools in Indonesia spread across seven provinces (Jakarta, Banten, West Java, Central Java, Riau Island, NTT, and East Kalimantan).

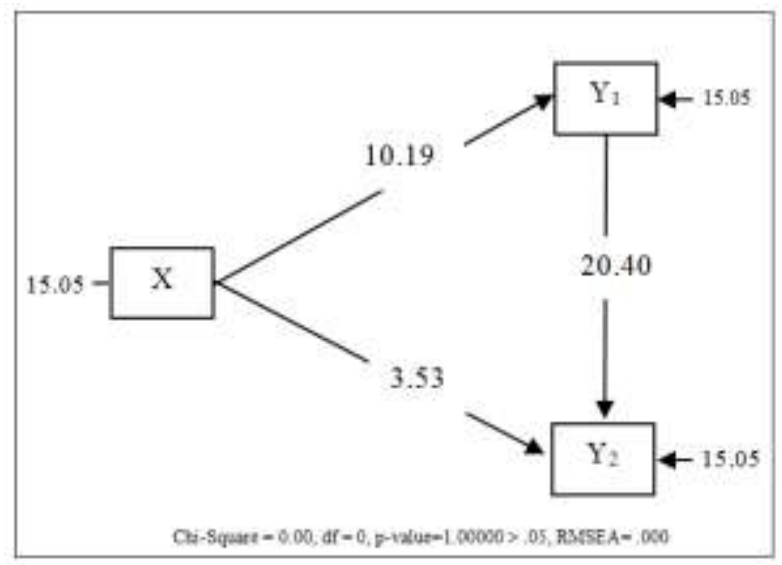

Fig-2: T Values

This empirical fact confirms that SOJ and OCB are vital for teachers' performance so that it needs to manage and develop optimally and adequately. Consequently, school principals need to more seriously increase SOJ in the school, potentially enhancing teachers' OCB and teachers' performance. In the SOJ context, school principals need to adequately apply distributive, procedural, and interactional justice [10]. Regarding teachers' OCB, school principals need to creating school conditions that can encourage teachers' OCB reflected in good altruism, awareness, sportsmanship, courtesy, and civic virtue. This kindness will have implications for the school organizations' effectiveness and performance, which is needed to improve the quality of education output and nations' human resources. 
Finally, the research results found an empirical model of SOJ on teachers' performance mediating by OCB based on data from teachers of the public elementary school in Indonesia was confirmed. This model can discuss among researchers and educational practitioners to build models of performance that can adopt as new approaches or strategies to enhancing teachers' performance.

\section{CONCLUSION}

This research result concluded that SOJ and OCB significantly affect teachers' performance. SOJ is also significantly influenced teachers' performance. Besides, OCB is indirectly mediating the effect of SOJ on teachers' performance. The empirical model of SOJ on performance mediating by OCB was confirmed. This model can discuss among researchers and educational practitioners to build models of performance that can adapt as new approaches or strategies to enhancing teachers' performance. Therefore, the research suggested that the teachers' performance can improve through SOJ and OCB.

\section{REFERENCE}

1. Tahsildari, A., \& Shahnaei, S. (2015). Enhancing organizational effectiveness by performance appraisal, training, employee participation, and job definition. European Journal of Business and Management, 7(12), 56-67.

2. Fahmi, H. K., Musnadi, S., \& Nadirsyah. (2019). Role conflict, self-efficacy, employees' performance, and organizational performance. Journal of Accounting Research, Organization, and Economics, 2(1), 31-40.

3. Aguinis, H. (2018). Performance management $\left(4^{\text {th }}\right.$ ed.). Illinois: Chicago Business Press.

4. Ivancevich, J. M., Konopaske, R., \& Matteson, M. T. (2018). Organizational behavior \& management (1 $11^{\text {th }} e d$.). New York: McGraw-Hill Education.

5. Colquitt, J. A., Lepine, J. A., \& Wesson, M. J. (2019). Organizational behavior: Improving performance and commitment in the workplace $\left(6^{\text {th }}\right.$ ed.). New York: McGraw Hill Education Limited.

6. Muchinsky, P. M. (2006). Psychology applied to work: An introduction to industrial and organizational psychology. Belmont, CA: Thomson/Wadsworth.

7. Schultz, D., \& Schultz, S. E. (2016). Psychology and work today. New Jersey: Routledge.

8. Greenberg, J., \& Baron, R. A. (2010). Behavior in organizations. Pearson international edition $\left(10^{\text {th }} e d.\right)$. New Jersey: Pearson Prentice-Hall.

9. Asadullah, M. A., Akram, A., Imran, H., \& Arain, G. A. (2017). When and which employees feel obliged: a personality perspective of how organizational identification develops. Rev. Psicol.
Del Trabajo y de las Organ, 33, 125-135. http://doi:10.1016/j.rpto.2017.02.002.

10. Aamodt, M. G. (2016). Industrial/organizational psychology: An applied approach. 8th edition. Belmont, CA: Thomson Learning, Inc.

11. Shan, S., Ishaq, H. M., \& Shaheen, M. A. (2015). Impact of organizational justice on job performance in libraries, Library Management, 36(1/2), 70-85. http://dx.doi.org/10.1108/LM-012014-0003

12. Nurak, L. A. D., \& Riana, I. G. (2017). Examine the effect of organizational justice on job satisfaction and employee performance. J Mgt Mkt Review, 2(3), 30 - 37.

13. Krishnan, R., Loon, K. W., Ahmad, N. A. F., \& Yunus, N. A. S. (2018). Examining the relationship between organizational justice and job performance. International Journal of Academic Research in Business and Social Sciences, 8(3), 484-495.

14. Aditya, C. P. D. (2019). Leadership, organizational culture, organizational justice on organizational commitments and employee performance contract in private hospitals. Jurnal Manajemen Bisnis, 16(3), 151-166. https://doi.org/10.38043/jmb.v16i3.2238

15. Purnama, Y. H., Tjahjono, H. K., Assery, S. M., \& Dzakiyullah, N. R. (2020). The relationship of organizational justice on job satisfaction and job performance in banking company. International Journal of Scientific \& Technology Research, 9(03), 4012-4015.

16. Barsulai, S. C., Makopondo, R. O. B., Fwaya, E. V. O. (2019). The effect of organizational citizenship behavior on employee productivity in star-rated hotels in Kenya. European Journal of Hospitality and Tourism Research, 7(1), 1-8.

17. Sadeghi, G., Ahmadi, M., \& Yazdi, M.T. (2016). The relationship between organizational citizenship behavior and organizational performance (Case study: Agricultural Jihad Organization of Mazandaran Province). Problems and Perspectives in Management, 14(3), 317-324. http://dx.doi.org/10.21511/ppm. 14(3-si).2016.03.

18. Kreitner, R., \& Kinicki, A. (2013). Organizational behavior $\left(9^{\text {th }}\right.$ ed.). New York: McGraw-Hill Irwin.

19. McShane, S. L., \& Von Glinow, M. A. (2018). Organizational behavior: Emerging knowledge, global reality ( $8^{\text {th }}$ ed.). United States: McGraw-Hill Education.

20. Organ, D. W. (2018). The roots of organizational citizenship behavior. In: Podsakoff, P. M., MacKenzie, S. B., \& Podsakoff, N. P. (eds.). The oxford handbook of organizational citizenship behavior. Oxford Library of Psychology. Oxford: Oxford University Press, 7-18.

21. Organ, D. W., Podsakoff, P. M., \& MacKenzie, S. B. (2006). Organizational citizenship behavior: Its 
nature, antecedents, and consequences. California: Sage Publications, Inc.

22. Hidayah, S., \& Harnoto. (2018). Role of organizational citizenship behavior (OCB), perception of justice, and job satisfaction on employee performance. Jurnal Dinamika Manajemen, 9(2), 170-178. https://doi: 10.15294/jdm.v9i2.14191.

23. Lestari, E.R., \& Ghaby, N.K.F. (2018). The influence of organizational citizenship behavior (OCB) on employee's job satisfaction and performance. Industria: Jurnal Teknologi dan Manajemen Agroindustri, 7(2), 116-123. https://doi: 10.21776/ub.industria.2018.007.02.6.

24. Hermawan, H., Thamrin, H. M., \& Susilo, P. (2020). Organizational citizenship behavior and performance: the role of employee engagement. Journal of Asian Finance, Economics and Business, 7(12), 10891097. https://doi:10.13106/jafeb.2020.vol7.no12.1 089.

25. Udin, U., \& Yuniawan, A. (2020). Psychological capital, personality traits of big-five, organizational citizenship behavior, and task performance: Testing their relationships. Journal of Asian Finance, Economics and Business, 7(9), 781-790. https://doi.org/10.13106/jafeb.2020. vol7.no9.781.

26. Pan, X., Chen, M., Hao, Z., \& Bi, W. (2018). The effects of organizational justice on positive organizational behavior: Evidence from a largesample survey and a situational experiment. Front. Psychol, 8, 1-16. DOI: 10.3389/fpsyg.2017.02315.

27. Farid, T., Iqbal, S., Ma, J., Castro-González, S., Khattak, A., \& Khan, M. K. (2019). Employees' perceptions of CSR, work engagement, and organizational citizenship behavior: The mediating effects of organizational justice. Int. J. Environ. Res. Public Health, 16, 1-16. doi:10.3390/ijerph16101731

28. Odor, H. O., Martins-Emesom, J.N., \& Ugbechie, K.C. (2019). Organizational justice as a determinant of organizational citizenship behavior among Adhoc Lecturers of Delta State Polytechnic Ogwashi Uku, Nigeria. Management and Organizational Studies, 6(2), 9-23.
29. Al-ali, A.H., Qalaja, L.K., \& Abu-Rumman, A. (2019). Justice in organizations and its impact on organizational citizenship behaviors: A multidimensional approach. Cogent Business \& Management, 6, 1-18. http://doi: 10.1080/23311975.2019.1698792

30. Donglong, Z., Taejun, C., Julie, A., \& Sanghun, L. (2020). The structural relationship between organizational justice and organizational citizenship behavior in university faculty in China: the mediating effect of organizational commitment. Asia Pacific Education Review, 21, 167-179.

31. Ajlouni, W.M.E., Kaur, G, Alomari, S.A. (2021). Effective organizational justice and organizational citizenship behavior using fuzzy logic to obtain the optimal relationship. Qual Manag Health Care. 01, 30(1), 13-20. http://doi:10.1097/QMH.0000000000000288.

32. Mallick, E., Pradhan, R. K., Tewari, H. R., \& Jena, L. K. (2014). Organizational citizenship behavior, job performance, and HR practices: A relational perspective. Management and Labour Studies, 39(4) 449460. https://doi.org/10.1177/0258042X15578023.

33. Andrew, S. A., \& León-Cázares, F. (2015). Mediating effects of organizational citizenship behavior on organizational performance: Empirical analysis of public employees in Guadalajara, Mexico. EconoQuantum, 12(2), 7192.

34. Aval, S. M., Keikha, A., \& Haddadi, E. (2017). Investigating the effect of organizational citizenship behavior (OCB) components on organizational agility. Interdisciplinary Journal of Education, 1(2), 59-67.

35. Hair, J. F., Babin, B. J., Anderson, R. E., \& Black, W. C. (2018). Multivariate data analysis $\left(8^{\text {th }}\right.$ ed.). India: Cengage India.

36. van Griethuijsen, R. A., van Eijck, M. W., Haste, H., den Brok, P. J., Skinner, N. C., Mansour, N., ... \& BouJaoude, S. (2015). Global patterns in students' views of science and interest in science. Research in science education, 45(4), 581-603.

37. Widodo, W. (2019). Metodologi penelitian populer \& praktis. Depok: Rajawali Pers.

Cite This Article: C. Chandrawaty \& W. Widodo (2021). Investigating OCB's Mediating Effect of School Organizational Justice on Teachers' Performance: Evidence from Indonesia. East African Scholars J Edu Humanit Lit, 4(4), 167-172. 